\title{
DISTINGUISHING THE TWO FORMS OF EGYPTIAN AEDES (OCHLEROTATUS) CASPIUS PALIAS SPECIES (DIPTERA: CULICIDAE) BY ULTRA STRUCTURE MICROGRAPHS OF EGGS
}

By

\author{
B. A. SOLIMAN ${ }^{1}$, N. M. WASSIM ${ }^{1}$, AND J. R. LINLEY ${ }^{2}$ \\ Department of Zoology ${ }^{1}$, Suez University, Suez, Egypt and Florida Medical \\ Entomology Laboratory ${ }^{2}$, Institute of Food and Agricultural Sciences, \\ University of Florida, USA.
}

\begin{abstract}
Ultrastructure of the two forms autogenous and anautogenous eggs of Aedes (Ochlerotatus) caspius of Egypt are described using Scanning Electron Microscope (SEM). The eggs of the two forms are slightly boat shape with quite difference in width. Chorionic cells of the ventral surface are ultimately different in both forms in shape, width of reticulum , number and size of tubercles. The chorionic cells of the autogenous form's egg are elongate, narrow and almost curved with unusually wide, outer reticulum contain 2 - 13 large tubercles along with a few number in small size. However, the anautogenous form's egg, the chorionic cells of the ventral surface fairly distinct, very regular in outline with thin reticulum and usually hexagonal, each cell contain one or two large tubercles with many small scattered peripheral tubercles. Fine structure micrographic work of eggs of the Egyptian Ae. caspius provides new morphological evidence that both autogenous and unautogenous forms are certainly different and suggests that those forms are two distinct species.
\end{abstract}

Key Words: Mosquitoes, Aedes caspius, Eggs, Scanning Electron Microscope.

\section{Introduction}

Aedes caspius Pallas is a widely distributed in the Palaearctic Region where its larvae were primarily halophytic, with occasional occurrence in fresh water (Horsfall, 1955). It is one of exceedingly common and widely distributed mosquito species throughout different geographical areas in Egypt (Kirkpatrick, 1925; Harbach et al, 1988). This species has been incriminated to transmit Rift valley fever virus during the 1977 \& 1993 epidemics (Gad et al, 1987; Turell et al, 1996). Despite the wide spread abundance of this mosquito and its potential as disease vector, the fact that biology and taxonomy are not thoroughly established.

Recently, some studies focused on the ecology and biological attributes of the Egyptian Ae. caspius indicated that this species in Egypt exists in two discrete biological forms and it can be represented by a group of two distinct species. They had been identified as an autogenous, stenogamous form inhabiting brackish water breeding sites in coastal and inland desert areas, while an anautogenous, eurygamous form abounding in fresh water pools in agricultural areas (Gad et al, 1989; Farid et al, 1989a, b). Moreover, The two forms were observed sexually isolated either in nature or under laboratory conditions (Hassan, 1991). Also, isozyme analysis indicated the presence of two sympatric gamodemes in its population (Farid et al, 1989a). Gad et al. (1992) addressed a phenotypic profile of both Ae. caspius forms using the EST and $\mathrm{ME}$ enzymes as fingerprint for both forms. Despite some molecular tools; RAPD-DNA markers, the second Internal Transcribed Spacer Region of ribosomal DNA (ITS2rDNA) and microsatellite of the acetyl cholinesterase gene have been used to distinguish the two forms of Ae. caspius (Wassim et al, 2013 and Wassim et al, 
2014), the taxonomic status of those forms in Egypt needs a morph metrics analysis .

The present study used the ultra-structure scanning electron micrographs to confirm and distinguish both forms of Egyptian $A e$. caspius biological variants.

\section{Materials and Methods}

Eggs of Ae. caspius biological forms were collected from laboratory colony (F1).The originating materials have been obtained in two isolated areas in Egypt. Autogenous mosquitoes were collected from coastal area of Suez Canal $120 \mathrm{~km}$ north east of Cairo, Ismilia Governorate, whereas anautogenous were originated from Al-gabal Al-asfer area located $12 \mathrm{Km}$ north Cairo, Qalyoubia Governorate. The autogenous mosquitoes were collected as larvae and pupae that were reared in sectary under controlled conditions $\left(27^{\circ} \mathrm{C} \pm 2, \quad 70-80 \% \mathrm{RH} \quad\right.$ and $\left.16: 8 \quad \mathrm{~L}: \mathrm{D}\right)$ photoperiod. Anautogenous mosquitoes were collected as adults at sun set time, gravid females were held in separate propylene tubes individually in the controlled in sectary till egg lying. Eggs laid on filter paper by each female then washed off into alcoholic Bouin, fixative, sealed vials along with mosquito female labeled with same coding till examination using ESM. Procedures for preparing and examining the eggs were as described by Linley et al. (1993a); Linley and Service (1994\&1995). Eggs were set with a fine artist's brush on stubs coated with sticky tape, dried finally over calcium chloride (30 min) then coated with gold and examined with a Hitachi S-I5I 0 SEM.

Measurements were obtained from micrographs using digitized tablet. Quantitative attributes of the chorionic cells and associated structures derived from an equal number of measurements from three eggs of each form. Lengths of the chorionic cells measured across the longitudinal axis while width measured across the circumferential axis. The width of the egg measured at the widest point of the egg; cell length and width were measured from the midpoints of the reticulum. Measurements scored as means $\pm \mathrm{SE}$ in the text and table; the differences between them tested by the T-test and or a range. Terminology adapted was after Harbach and knight (1980); Linely (1989) and Linley et al. (1991a, b).

\section{Results}

Aedes (Oclerotatus) caspius Autogenous (Tab. 1): Color: Matte Black.

Overall shape: boat-shaped in dorsal and ventral view, width greatest just anterior to middle, slightly more pointed in posterior (Fig.1A). Ventral side more arched in lateral view while dorsal side is flatted. Micropylar collar fairly inconspicuous, boundaries of outer chorionic cell field mostly rounded not angular, each contain several tubercles (Fig .1B).

Chorine, ventral surface: Outer chorionic cells usually hexagonal, rounded not angular corner, some are roughly pentagonal, length greater (mean 29.4 $\pm 0.04, \mu \mathrm{rn} n=20$ ) than width (mean $17.02 \pm 0.04, \mathrm{n}=20$ ), as indicated in length/width ratio (mean $1.7 \mathrm{~S} \pm 0.0 \mathrm{~S}$ ). Cell fields 4-7 urn less in each dimension, floors fairly smooth (Table $1 \&$ Fig. 1C). Each cell with 4-13 (8.2 $\pm 0.4, n=25)$ medium size tubercles (Fig. ID), diameter 1.1-5.8 $\mu \mathrm{rn}$ $(2.7 \pm 0.2 \mu \mathrm{rn}, \mathrm{n}=23)$, mostly arranged close to periphery of cell field (Fig. 1C\&D). Tubercles quite elevated, basal portions smooth, tops domed, slightly nodular (Fig. ID). Some cells with filamentous strands adhering to or between tubercles. Outer chorionic reticulum fairly wide (4-6 $\mu \mathrm{rn})$ widest near and at cell corners, elevated at edges, slightly concave with a central line of tiny papillae connected to low, transfer ridges. Reticulum with perforated surface associated with minute pores (Fig. ID\&E).

Aedes (Ochlerotatus) caspius Anautogenous (Tab. 1): Colour: Matte Black.

Overall shape: boat-shaped in dorsal and ventral view, width greatest just anterior to middle posterior end slightly more pointed. Ventral side arched in lateral view while the 
dorsal side is flatter, boundaries of outer chorionic cell distinct and very regular in outline, each contain considerable number of tubercles varied in Size (Fig. 2-A\&B).

Chorine, ventral surface: Cells hexagonal sometimes are pentagonal (Fig. 2-C), length greater (mean $37.1 \pm 0.07 \mu \mathrm{m}, \mathrm{n}=20$ ) than width (mean $22.9 \pm 0.05 \mu \mathrm{m}, \mathrm{n}=20$ ), as indicated length/ width ratio $(1.62 \pm 0.3 \mu \mathrm{m})$

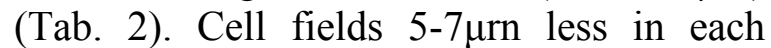
dimension. Almost all cells containing 1 or 2 prominent, centrally positioned large tubercle (mean $2.0 \pm 0.3 \mu \mathrm{m}, \mathrm{n}=23$ ) diameter
5.9-8.1 (mean $\quad 7.0 \pm 0.02 \mu \mathrm{m}, \quad \mathrm{n}=20$ ) surrounded by small tubercles 13-26 in number (mean $20.9 \pm 0.99, \mathrm{n}=23$ ), mostly and others close to the periphery of the cell field. The tubercles elevated, basal portions smooth, tops domed, slightly nodular (Fig.2D). Outer chorionic reticulum wide conspicuously rose; but narrows (width 2-3 $\mu \mathrm{rn})$ widest near and at cell corners, elevated at edges. Reticulum with small perforations associated with few minute pores (Fig.2 $\mathrm{D} \& \mathrm{E})$.

Table 1: Dimensions $(\mu \mathrm{m})$ of eggs of Egyptian autogenous $(n=19)$ and unautogenous $(n=17)$ Aedes caspius forms.

\begin{tabular}{|l|cc|cc|cr|}
\hline \multirow{2}{*}{ Mosquito form } & \multicolumn{2}{|c|}{ Lenghth $(\mu \mathrm{m})$} & \multicolumn{2}{c|}{ Width $(\mu \mathrm{m})$} & \multicolumn{2}{c|}{$\mathrm{L} \backslash \mathrm{W}(\mu \mathrm{m})$} \\
\cline { 2 - 7 } & $\mathrm{X}+\mathrm{SE}$ & Range & $\mathrm{X}+\mathrm{SE}$ & Range & $\mathrm{X}+\mathrm{SE}$ & Range \\
\hline Autogenous & $644.2 \pm 9.7$ & $562.6-702.6$ & $253.5 \pm 13.5$ & $200.6-379.9$ & $2.6 \underline{ \pm} 0.13$ & $1.7-3.4$ \\
\hline Unanautogenous & $641.4 \pm 10.4$ & $558.6-704.6$ & $192.72 \pm 2.86$ & $177.8-218.2$ & $3.3 \pm 0.05$ & $301-3.74$ \\
\hline
\end{tabular}

Table 2: Dimensions $(\mu \mathrm{m})$ of the chorionic cell of eggs of Egyptian autogenous and unautogenous Ae. caspius forms $(\mathrm{n}=20)$.

\begin{tabular}{|l|cc|cc|cr|}
\hline \multirow{2}{*}{ Mosquito form } & \multicolumn{2}{|c|}{ Lenghth $(\mu \mathrm{m})$} & \multicolumn{2}{c|}{ Width $(\mu \mathrm{m})$} & \multicolumn{2}{c|}{ L।W $(\mu \mathrm{m})$} \\
\cline { 2 - 7 } & \multicolumn{1}{|c|}{$\mathrm{X}+\mathrm{SE}$} & Range & $\mathrm{X}+\mathrm{SE}$ & Range & $\mathrm{X}+\mathrm{SE}$ & \multicolumn{1}{c|}{ Range } \\
\hline Autogenous & $29.4 \pm 0.04$ & $26.1-34.1$ & $17.02 \pm 0.04$ & $13.3-23.6$ & $1.75 \pm 0.05$ & $1.34-2.5$ \\
\hline U-anautogenous & $37.1+0.07$ & $28.3-42.7$ & $22.9+0.05$ & $17.1-26.7$ & $1.62+0.05$ & $1.22-2.17$ \\
\hline
\end{tabular}

\section{Discussion}

Several fine morphological structures of Mosquito eggs are useful to distinguish cryptic species (Lounibos et al, 1997; Sawabe and Morbayashi, 2000; Sallum and Flores, 2004; Suman et al, 2008, 2011). To clarify the taxonomic status of Ae. caspius in Egypt, it would be wanted to compare the fine structure of the egg's shell of both Egyptian Ae. caspius autogenous and anautogenous forms since adult and larval stages of both forms are virtually indistinguishable. A striking feature of the egg of Ae. caspius is the width of the chorionic reticulum. In other species of Ochlerotatus. It ranges on the ventral surface from 1.4-2.4 pm in diameter in $A e$. theobaldi (Taylor), Ae. sugux (Skuse) and Ae. procax (Skuse) (Linley et al, 1992a), to 0.9-3.2 pm in Ae. infirmatus Dyar and Knab (Linley, 1990) and 3.0-3.3 pm in Ae. vigifux (Skuse) (Linley et al, 1992b). The Ae. caspius reticulum $(4.0-6.0 \mu \mathrm{rn}$ wide) exceeds all these so that the cell fields appear unusually small (Fig. 1). As a proportion of the total cell area in nine ventral cells in the middle of the egg, the field comprised a mean of only $46.9 \mathrm{f} 1.2 \%$ in Ae. caspius, as compared with $69.4 \mathrm{f}$ $1.3 \%$ in Ae. procax (measured from file micrograph) Linely et al. (1992b).

The present work revealed certifies differences in chorionic pattern of both forms in addition to that differences observed in width of eggs. Results of dimensions of the autogenous form's egg are identical to that observed on eggs of $\mathrm{Ae}$ caspius obtained from salt marsh, Ismialia, Egypt (Linley et al., 1993-b). As striking feature characterize the eggs of Ae. caspius mosquito is the width of chorionic reticulum on the ventral surface of the egg which ranges from 4.0-6.0. Data obtained revealed that the width of the chorionic cells in the 
investigated Ae. caspuis forms is different; the width of chorionic reticulum of The autogenous form is close to that estimated by Linley et al., (1993-b ) and equals two folds of the anutogenous eggs, which showed low range 2.3-3.1 $\mu \mathrm{rn}$. The present study reflects meaningful comparison between two forms of Egyptian Ae. caspius and it is revealed that fine structure micrograph works on eggs of Ae. caspius showed a strong unique morphological difference between both forms.

According to Marshall (1938) eggs of Ae. caspius are laid in vegetation covering the larval habitats. Under the SEM, Linely et al.,(1993-b) found no material adhering to the chorine, which might be suggested that the eggs are glued to the ovipositor substrate. The two forms of Ae. caspius are observed sexually isolated either in nature or under laboratory conditions The autogenous form is stenogamous and inhabiting brackish water breeding sites in coastal and inland desert areas. On the other hand the anautogenous form is eurogamous and abounding in fresh water pools in agricultural areas (Hassan, 1991); there is no hybrid form as in case of Culex pipiens, that is meaning there is no gene flow between the two forms. The genotype variations of the two forms of Ae caspius had been confirmed (Farid et al, 1989; Wassim et al, 2013; Wassim et al, 2014), so, this explain the difference in phenotypes of the eggs of those forms. Harbach et al., (1983) didn't find in their early surveillance none of the specimen described by Kirkpatrick, (1925) and couldn't collect any sample from the type localities in Egypt (Kafr Eldauwar, Ae. willcokasii Theobald and Port Said Type locality of Ae. affricanus Neveu-Lemaire and suggested that the two forms of $A e$. caspius are two separate species.

\section{Conclusion}

It can be concluded that using the ultrastructure micrographs to distinguish the two forms of Ae. caspius in Egypt showed clear and significant differences and come together with the genotyping studies had been done to differentiate those forms and confirmed Harbach (1983) that the authors are dealing with two species.

\section{Acknowledgement}

The authors would like to thank D. Duzak, Food and Agricultral Sciences, University of Florida Experiment Stations, for printing the the micrographs.

\section{References}

Bullini, L, Coluzzi, M, 1982: Evolutionary and Taxonomic inference of electrophorai studies on mosquito: Recent Developments in the genetics of insect disease vectors. Stips Publication Company, Champing, IL.

Farid, HA, Gad, AM, El-Said, S, 1989a: Heterozygote deficiency In natural popu-lations of Aedes caspius Palls from Egypt. J. Egypt. Publ. Hlth. Assoc. 64:445-9.

Farid, HA, Gad, AM, Hassan, MM, 1989b: Bi-autogenous ovarian cycles in Egyptian Aedes caspius Pallas (Diptera: Culicidae). J. Egypt. Publ. Hlth. Assoc. 64:534-45.

Gad, AM, Hassan, MM, EI- Said, S, Mou-ssa, ML, Wood, OL, 1987: Rift Valley fever transmission by different Egyptian mosquito species. Trans. Roy. Soc. Trop. Med. Hyg. 81:694-8.

Gad, AM, Hassan, MM, Farid, HA, 1989: Facultative blood feeding by nulliparousautogenous Egyptian Aedes caspius Pallas (Diptera: Culicidae). J. Egypt. Publ. Hlth. Assoc. 64:266-79.

Harbach, RE, Harrison, BA, Gad, AM, Kenawy, MA, El-Said, S, 1988: Records and Notes on mosquitoes (Diptera: Culicidae) in Egypt. Mosq. Syst. 20, 3:317-42.

Harbach, RE, Knight, KL, 1980: Taxonomists Glossary of Mosquito Anatomy. Plexus Publishing: Marlton, New Jersey, USA.

Harbach, RE, Peyton, EL, Jakob, WL, 1983: Synonymy of Culex (Culex) oswaldoi with Culex (Culex) maxi (Diptera: Culici-dae). Mosq. Syst. 15:310-7. 
Horsfall, WR, 1955: Mosquitoes, Their Bionomics and Relation to Disease. Hafner Publishing Co., New York.

Kirkpatrick, TWL, 1925: The mosquitoes of Egypt: Egypt Government anti -malaria, Cairo, Egypt.

Linley, JR, 1989: Comparative fine structure of the eggs of Aedes albopictus, Aedes aegypti and Aedes bahamensis (Diptera: Culicidae). J. Med. Ent. 26:510-21.

Linley, JR, Abo Ghalia, AH, Soliman, BA, Mukwaya, G, 1993b: The eggs of Aedes caspius and Aedes Africans (Diptera: Culicidae) Mosq. Syst. 25, 1:25-34.

Linley, JR, Duzak，D， Linley，JR， 1997: Comparative egg morphology of six species of the Albimanus section of Anopheles (Nyssorhynchus) (Diptera: Culicidae). J. Med. Ent. 34, 2:136-55.

Linley, JR, Geary, MJ, Russell, RC, 1991: The eggs of Aedes (Fnlaya) albolotus and Aedes (Fznlaya) rubrithiorax (Diptera: Culicidae). Mosq. Syst. 23, 2:132-43.

Linley, JR, Geary, MJ, Russell, RC, 1992a: Fine structure of the eggs Aedes (Ochlerotatus) Theobald, Ae. (Och.) sagax and Ae. (Och.) procax (Diptera: Culicidae). Mosq. Syst. 23, 2:144-59.

Linley, JR, Geary, MJ, Russell, RC, 1992b: The eggs of Aedes vigilax and Aedes vittiger (Diptera: Culicidae). Proc. Ent. Soc. Washington 94:48-58.

Linley, JR, Lounibos, LP, 1993a: The eggs of Anopheles (Nyssorhynchus) range-li and Anopheles (Nyssorhynchus) dunhami (Di-ptera: Culicidae). Mosq. Syst. 25:157-69.

Linley, JR, Lounibos, LP, 1994: The remarkable egg of Anopheles peryassui (Diptera: Culicidae). Mosq. Syst. 26:25-34.

Linley, JR, Lounibos, LP, Conn, J, Duz- ak, D, Nishimura, N, 1996: A description and morphometric comparison of eggs from eight geographic populations of the South American malaria vector Anopheles (Nyssorhynchus) nuneztovari (Diptera: Culicidae). J. Am. Mosq. Cont. Assoc. 12: 275-292.

Linley, JR, Milstrey, EG, 1995: The eggs of Anopheles (Anopheles) mattogrossensis and Chagasia fajardi (Diptera: Culicidae). Mosq. Syst. 27:27-39.

Marshal, LF, 1938: The British mosquitoes British Museum (Natural History), London.

Saleh, NM, 2012: Aedes mosquito in Aswan Governorate, Egypt. J. Egypt. Soc. Parasitol. 42, 1:233-8.

Sallum, MAM, Flores, DC, 2004: Ultra structure of the eggs of two species of Anopheles (Anopheles) Meigen (Diptera: Culicidae) Rev. Brasil. de Ent. 48, 2:185-92.

Sawabe, K, Moribayashi, A, 2000: Lipid utilization for ovarian development in an autogenous mosquito, Culex pipiens molestus (Diptera: Culicidae). J. Med. Ent. 37, 5: 726-31. Suman, DS, Shrivastava, AR, Pant, SC, Parashar, BD, 2011: Differentiation of Aedes aegypti and Aedes albopictus (Diptera: Culicidae) with egg surface morphology and morphometrics using Scanning Electron Microscope. Arthropod Struct. Dev. 40, 5:47983.

Suman, DS, Shrivastava, AR, Parashar, BD, Pant, SC, Agrawal, OP, 2008: Scanning Electron Microscopic studies on egg surface morphology and morphometrics of Culex tritaeniorhynchus and Culex quinquefasciatus (Diptera: Culicidae).

Parasitol Res 104:173-176.

Wassim, NM, Soliman, BA, Shoukry, A, Kashef AH, 2014: Molecular genetic variations of different populations of Aedes caspius (Pallas) from different geographical habitats. In press.

Wassim, NM, Soliman, BA, Yamani, DF, Abdel Nabi, IM, 2013: Rapid assay to differentiate the two forms of Egyp-tian Aedes caspius (Diptera: Culicidae) using acetyl cholinesterase gene. J. Basic Appl. Zool. 66, 1:12-7. 

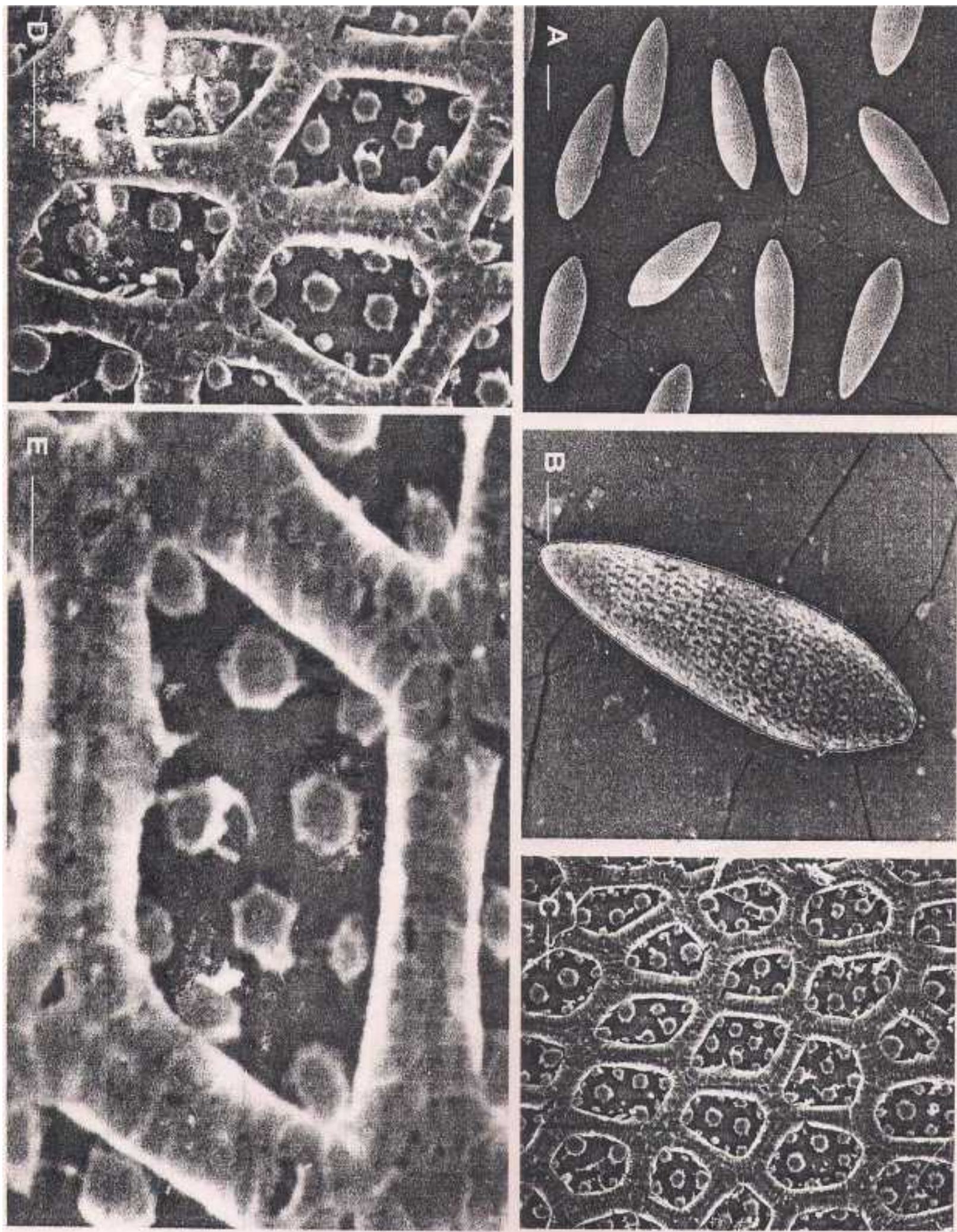

Fig. 1: Aedes caspius Autogenous (A) Egg batch, (B) Entire egg lateral view,(C) Outer chorionic cells, ventral surface middle of egg ,( D) Detail single lateral cell,(E) Tubercel and outer chorionic reticulum. 

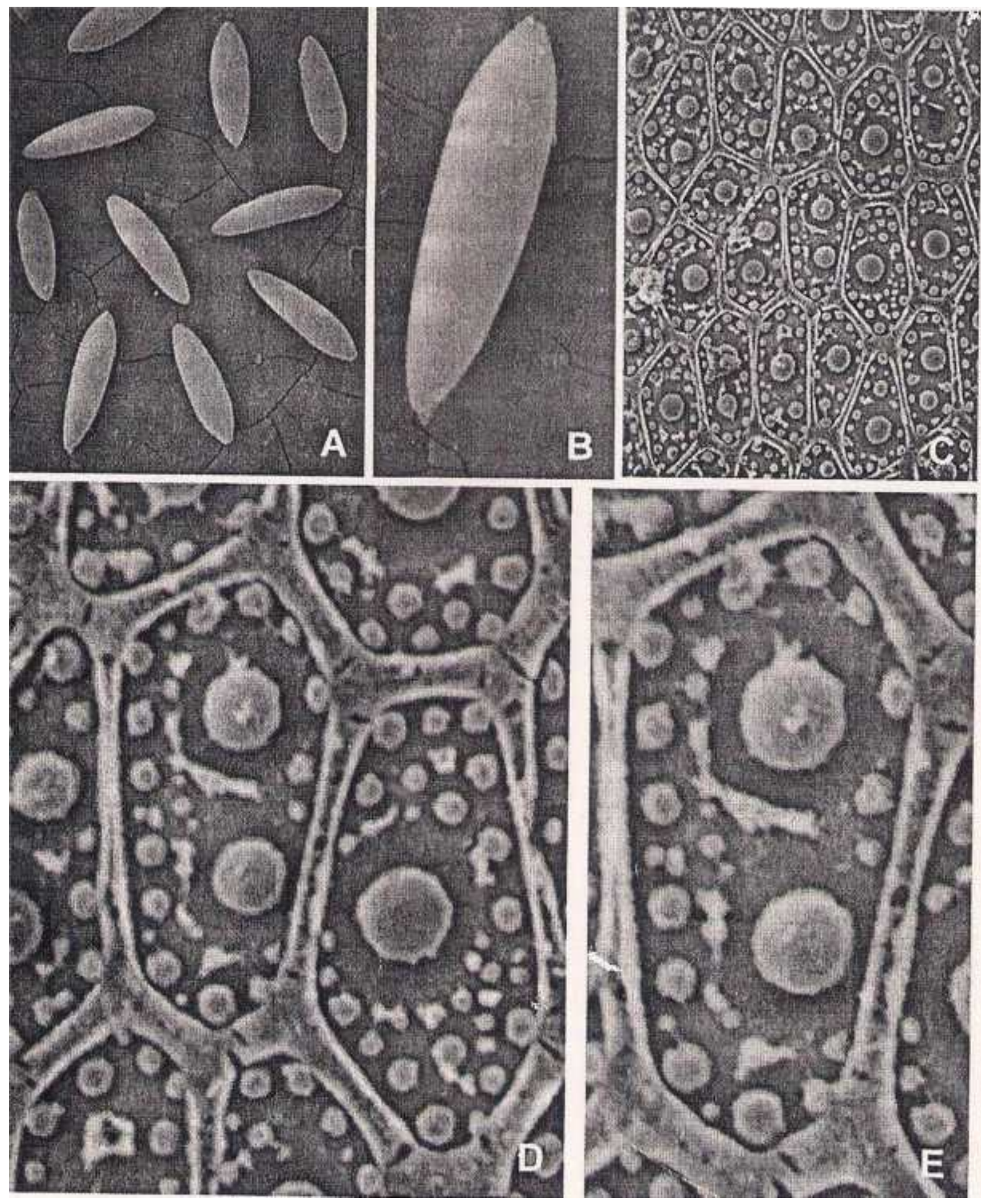

Fig. 2: Ae. caspius Anautogenous (A) Egg batch, (B) Entire egg lateral view,(C) Outer chorionic cells, ventral surface middle of egg ,(D) Detail single lateral cell,(E) Tubercel and outer chorionic reticulum. 